\title{
Development as Intended Transformation
}

\author{
Efim Ya. Kogan* \\ Federal Institute of Education Development \\ Volga Branch \\ 37 Maslennikov, Samara, 443056, Russia
}

Received 07.09.2014, received in revised form 18.10.2014, accepted 19.11.2014

\begin{abstract}
The present article is dedicated to the problem of the conceptual meaning of "development" term. In the initial position of the analysis, it is set forward in the aspect of adaptation to a new task solution. At the same time, it is suggested that any new task set for an individual or an organization creates a problem of a mismatch between the current resources and the level of the set task. The process of development is the resolution of this non-compliance. Neither the research of the past experience nor the review of the present can change the core of the organization as activity or activity simulation. The only factor that starts development is a pre-set objective, providing activity with a certain vector. There is no development without objective. This thesis is demonstrated on the example of one existing project, reviewed in detail in the paragraph dedicated to organization development logic. It is used to show the systematic development principle, the necessity to adjust the existing infrastructure to a new task and to build a new one, to transform the basics of the human resources' preparation system. Basically, the reference organization needed re-engineering of the business process for providing the swiftly revolving technologies of a modern industry with appropriate human resources. As a result, it is suggested to create an adjustable model of organizing educational resources, thereby switching organizations to the mode of self-sufficient adjustment to the changing labor market demand within the current paradigm of economic development of the region.
\end{abstract}

Keywords: development, labor markets, adjustment, educational resources, human potential, human resources.

Research area: pedagogy, psychology.

What does the term "development" mean for management? It is not an idle inquiry, because its answer is what the reaction to the organization development inquiry, resource dynamics and the efficiency of its activity depend on as a whole. Development programs have already become essential for various educational institutions, from pre-school to higher education. Businesses build their activity in accordance with their development program referred to as business project. Generally, it is quite reasonable: adequate management today is impossible without the idea of its tomorrow's results. This is an evident dogma. The question is, when and under what conditions "tomorrow" makes up the development of "today"? When is a reference to development truly reasonable? And finally, what is the status of a manager and what is the structure of a development program? Let us tell you about one project executed by

(C) Siberian Federal University. All rights reserved

* Corresponding author E-mail address: efkogan@yandex.ru 
a company, presenting a classic example of a complex educational institution development.

To operate a term, one needs to define it, which means to identify its main features and prospective of use. For our objectives, the following definition is of greatest use: development is a process of adjustment to a new task, new challenge and new conditions. The gist and the meaning of a development process are matching into a new task by changing the company's resources. This statement clarifies the ways of organizing the development process, its consistency and, most important, its result as readiness to solve the pre-set task. It is important to remark that without a new task there is no development. Only a new task, replacement of standards, new activity conditions can make the company's resources and activity obsolete under the new conditions. Basically, development process means removing this contradiction. What resource is the subject matter of this concept? First of all, it is human resource, the personnel that finds themselves de-qualified at the moment the new work conditions emerge. The next one is the organizational and management system that provides the capacity and adjustability of the company as long as it is supposed to reflect its functional structure. The latter is formed as operationalization of tasks, thereby requiring some corrections under the new task conditions.

The technologies attracted for achieving the preset result are the next type of resource. New quality product may only be made possible with an adequate technology involved. Speaking of educational institutions, the subject matter is educational technologies. Moreover, they are not limited to the technologies (methodologies) of subject teaching; they also include the ways of organizing educational activities, educational programs of any type, requiring certain facilities. The business organization form of an educational institution providing the optimal set of rights and responsibilities for efficient functioning should also be taken into account as a resource.

As long as educational system has no any strategic objectives of its own, it takes up the objectives of "others" and organizes its resources in order to provide efficient service of such objectives. By the way, this is what educational system development means: it means organizing its resources for the solution of new tasks, providing the achievement of objectives lying beyond the system itself [1].

\section{"Examples are stronger than rules". Sir Isaac Newton}

The case studied below is a real practice of development in the sense quoted above, demonstrating all its stages starting from the reasons and problem setting to the creation of a brand new system of organizing the educational resource for solving the existing problem.

In the large industrial city of Tolyatti a series of modern manufactures, such as automotive industry, oil and chemical production, and construction industry are highly developed. The competition in these branches is very strong, which leads to frequent rises in the quality and range of the produced goods and services. Naturally, it is made possible by means of continuous modernization of production technologies. Every technology replacement requires special training or re-training of the personnel. This is the point where all the problems emerge... The managerial system of the professional education system was formed in the times and the circumstances when the life of a project, technology and actual knowledge was longer: longer in comparison with the professional life of a specialist. It means that the actions and techniques learned by a person would provide them with the capacity to perform their job functions for quite a long time. However, within the last decades the industrial production market situation changed: the life of 
technology, knowledge and all industrial products dramatically shortened. Unaware of the change, the educational system continued (and it still does) following the old pattern: the education standards and programs fall more and more behind the real practice and even the latest knowledge becomes obsolete as the training finishes. The increase of the human resource's quality cannot catch up with the evolution of technologies, labor functions and working techniques [2]. What is coming next?

1. The suppression of production technology evolution with the long period of human resource adaptation;

2. Decrease of labor efficiency;

3. Decrease of the region's investment attractiveness;

4. Decrease of the products' competitive ability.

Usually, in such cases the problem is the inability of the system to fulfill the due tasks with its old resources. It needs to start a process of development, embedding its system into the new conditions, adjusting it to them.

The main peculiarity of the fast-evolving knowledge-intensive industries is that the infrastructure, intended to provide the resource maintenance, including the human resources, is either absent or evolving significantly slower than needed. Under such conditions, the problem is the search of an adequate mechanism to provide an urgent solution to the fast-evolving industries' demand for human resources. It is required to train specialists in performing such job functions that either did not exist before or had their functions changed; in some cases, such jobs are even still expected to appear in the process of execution of some new innovative projects. The newly introduced technologies are often more than innovative, but unique in their branch. They have no analogues in Russian practice; however, they require new professional competences that have not yet been developed by the existing educational programs.

Under the conditions of such fast technology evolution, companies need to be regarded not as static systems, but as processes of transformation caused by the continuous variation of its balancing states. The operationalization of this principle means dramatic transformation of the management system in order to achieve the significant rise of functioning efficiency.

Management priority changes for the continuous monitoring of labor market demands, reflecting the competence condition of human resources. Today it is evident that as long as the organization of human resources is not determined by the labor market, the educational system loses its true orientation, while the academic format of personnel training is incapable of providing the contemporary, and certainly the prospective technologies with adequate specialists. To provide the efficient presence of the industries' interests in the education services' market it is required to build a new infrastructure acting as a

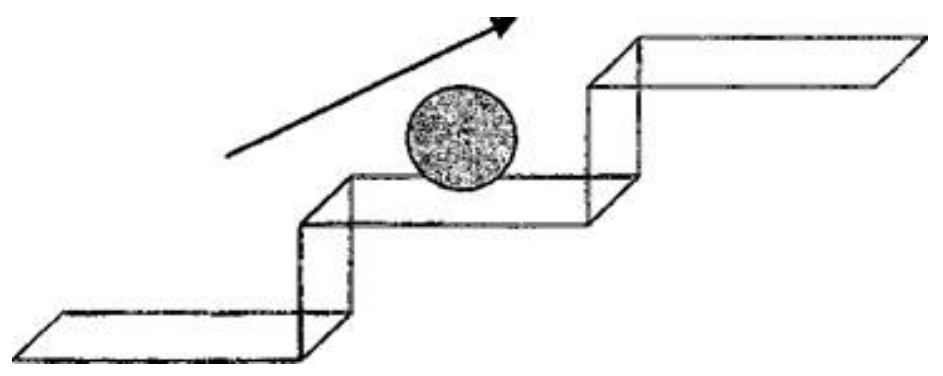

Fig. 1. Diagram of development as a continuous revolution of balancing states 
professional intermediary, supporting the priority of the labor market's demands in organizing the education services' market.

Under the new conditions, the labor markets' structure turns insufficient as it does not imply transmitting its own interests to the educational system. It is the "heritage of the old world", where this role was played by the state, and, moreover, the role was easy to play, as the interests were same and stable. The labor market needs to convey its need for urgent adaptation of the personnel to the new industrial technology to the market of educational services. For the Russian markets of labor and educational services it means a brand new way of task-setting, which may not be solved with the intermediaries present in the markets at the moment. Let us also note that the announced development process requires a new labor market infrastructure to be created.

In the labor market there are intermediaries that provide a wide range of services and may be presented as subjects of commercial, informational, educational, expertise and consulting businesses... In different countries such bodies are referred to as employment centers, labor registry offices, job bureaus, recruitment agencies. The bodies performing the informing, consulting, or any other assisting function in the labor purchase and sale relations make up a certain type of intermediaries in the labor market.

In this market the intermediaries play a specific role between the employer and the educational service market, providing monitoring of professional and labor needs in qualitative and quantitative aspects, informing such different target groups of users, as education management bodies, employers and population, about the labor qualifications demanded at the moment. The services of such intermediaries are urgent only under the conditions of rapid evolution of industrial technologies, when the new technologies have not yet become a subject of basic education programs but require to be known for special training of human resources according to the industries' needs.

The intermediation of this type in such a specific labor market sector includes:

1. Studies of the labor market demand for the adaptation of industries' personnel to new industrial tasks.

2. Acceptance of the industries' inquiries for providing the human resources for operating the newly implemented technologies;

3. Making up a list of professional competences required for fulfillment of the new industrial functions;

4. Placement of order for the development of new educational and personnel training programs;

5. Professional collection of the results and submitting them to the customer.

The inquiries are placed in the network of organizations authorized for running basic (master's) and / or additional professional educational programs. As a rule, this educational service market is presented by higher professional education and scientific institutions. Their main task is to develop an educational program of a certain level and to train the company's personnel according to the program.

The basic peculiarity of customized personnel training is to build and run an educational program for mastering some specific types of activities and industrial operations making up the job functions within a brand new technology with no experience of pedagogical interpretation of the employer's inquiry for training personnel of this certain professional qualification in the form of professional and other special competences.

Such a program is supposed to act as an educational technology, enabling the personnel to 
carry out their professional activity in their new technology jobs.

This way of conveying the qualification demand of the labor market provides efficient feedback for the education system. When the demand is defined, it is required to build a new type of infrastructure, professional standards and personnel qualification certification system. These are the resources used by the employer at the industry branch level, not at the company level, to announce their qualification preferences and to select personnel matching the preferences. But this is a task of a different scale; it is performed at the level of the state and does not constitute a part of planned development studied in this article [3].

“Organizations created for working under certain conditions may not be successful under any others" [4].

To "hear" the needs of the labor market announced by the intermediary, an educational institution needs to build the so-called "hearing organs": the structures converting the qualification inquiries into tasks for creating and improving the curricula. The next step is to bring the educational resources into compliance with the new program which means that the personnel needs to be taught how to work under the new program and to provide the material and managerial components of the program. It is important to manage these changes fast enough, while the inquiry remains actual. It is only possible if the educational organization has a body providing its adaptability.

The success of a development program depends on its consistency, on the ability of changes in one sector to enact, involve, and reflect the others. Without adapting them to new conditions we paralyze the main task solution process. This is the main reason of many failures many brand new projects go through.

The current organizational set-up of educational institutions is created for functioning under principally different conditions, formed in the age of directive economy and adapted to the following conditions:

- stable economic environment;

- long-lasting technologies, types of activities and operations, educational programs;

- imputed curriculum structure;

- internal resource use;

- absence of a proper labor market;

- absence of competition;

- institutional quality control.

Crisis is coming down like an avalanche: discreet at first, it is gradually growing in the depth of times: the inefficiency of further increase in the number of personnel for solution of the complicating managerial tasks, increase of the number of personnel in the middle management level for many years has been a solution for several factors including the complication of new tasks and learning methods, productivity of governmental institutions in the legislative regulation and education globalization. However, we faced a situation when increase in the personnel number became inefficient for satisfying the human resource consumer. The other side of the problem is non-linear growth of the number of educational institution personnel in relation to the number of students, who actually are the institution's product as such.

Under such circumstances the organizational set-up is intended to maintain the existing internal schedule of activity.

The new economy situation is different. The internal activity is dependent on the evolving external market conditions. The degree of adaptability determines the efficiency of the organization and its main resources:

- flexibility for fast adaptation to the evolution of labor and educational services' markets; 
- rationality, to be successful in price competition;

- innovation for the new formed competences to compensate the major part of the added value;

- customer orientation for maintaining the demand.

Marketing and market forecast become the leading types of a company's activities. This is where the development strategy tasks are formed and the internal resources for meeting the new market conditions are created. The second leading type of activity is the adaptation of the educational process resources to the evolving market's needs. It is the structure that created the new organizational and managerial set-up for the educational institutions along the regulations for the new structures and their interaction between themselves. It considers the increasing dynamics of all the processes caused by constant changes in the market needs, by the orientation of personnel training to the individual customer preferences, continuous technological improvement of real economy and high competition. As a result, educational institution management switches from managing separate resources and functional subdivisions to managing the processes that bond all the structures altogether.

It should be also considered that the labor markets have significantly changed their requirements. Now the employer is not interested in the formal presence of an academic degree; they want a list of competences and potentials the job candidate may provide:

- the main requirement is a competence, not a degree;

- the priority is given to key competences and behavioral qualities;

- competition shifts towards the potential resource area;

- intellectual component of professional activity gains more importance;
- subtle signals of the market are considered.

Let us also remark that forecasting technology development and labor market needs are equally important for the rational organization of general education, which is expected to provide students with long-lasting knowledge, skills, competences and professionalism. This circumstance establishes the following forecasting tasks:

- evaluation of the requirements imposed by the modern technologies on the knowledge, skills and competences of school graduates;

- establishment of professional training profiles, making up a list of general competences expected to remain in demand for the next 7-10 years.

These tasks require a new infrastructure to provide a reliable forecast that forms a base for the industrial strategies and development programs. It is another result of the regional education system development caused by the external challenges for the system.

The next step was made due to the change in the personnel training practice. It was needed to submit this process to the continuous education program evolution task. Personnel training used to begin before the new program introduction: as a rule, it would happen at the real production site. Such on-site trainings were the advanced training cycles which are now formed and announced by the real institutional program in order to fulfill a real task of creating new professional competences demanded by the labor market. Let us emphasize the significance of development consistency again: all the participants included into the final product making, specialists, organizations, and agents, need to adapt to the new task.

The same concerns the organization of the educational process of human resources [5]. It has to be oriented at the result, the final result, which is the new learned types of activities, 
not knowledge. This is the only way of training specialists with the minimum of time spent on adaptation to the job practice. The shift from knowledge as a training result to competences, bringing the knowledge from the category of objectives into the category of means meant a great evolution of the previous education practice and experience of the educational institutions' personnel. The present workers of training directorates of educational institutions are mastering the principles and methods for making up curricula in the forms of modules and competences, network organization programs, using resource centers in the curricula.

Teaching staff is learning the methods of forming general and professional competences, organizing educational activities for forming the competences, preparing regional resources for personnel training in using the new instruments of management and teaching activities.

Another peculiar feature of this model is organizing the advanced training of professional education staff in the mode of personification of state financial obligations.

The reference region enacted a Decree ${ }^{1}$ providing each employee with an "advance training coupon", a document confirming the right of its holder for guaranteed sponsorship of his/her advanced training once in five years. The Coupon Holder may select the institution, program, form and terms of the advanced training in accordance with the offered information and their own plans of new advanced training programs, determine the sequence of studying the curriculum modules. This is how the program and the model for regional education system development as a way of organizing its resources for the solution of new regional economy tasks were formed.

Let us mention one more time, that consistent and constructive development is always associated with getting coordinated with new tasks' solutions. By "new tasks" we mean that the current resources are insufficient for solving them. As a rule, the attempts to solve them with the old means are fruitless.

An important conclusion to make is that beyond the new tasks there is no development; internal re-organization of an institution either leads to its optimization for the sake of solving a new task (external for the institution) or is a reflection of the internal institutional interests, the nature of which lies beyond the topic of the present article.

\section{What happens next?}

In Russia, the strategic priority of innovative economy development is established on the governmental level ${ }^{2}$, basing the long-term economy development on the growth of its innovative segments. Innovative activity means performance of works and/or rendering of services aimed at:

- creation and organization of industries for manufacturing brand new products or products with brand-new application properties (goods, works, services);

- creation and application of new, or modernization of the existing means (technologies) of their production, distribution, and use;

- application of the structural, financial and economical, staff, information and other innovations (novelties) for manufacturing and distributing the products (goods, works, services), providing savings of costs or creating conditions for such savings.

One of the most important factors of innovative economy development is the outstripping staff recruitment for launching the self-improvement mechanisms of the innovative system and stabilizing its performance. It requires: 
- creation and development of training, re-training and advanced training of specialists within the innovative activity sphere;

- increasing the innovative education level of the middle and top level managers, forming a significant group of managers capable of initiating, preparing and successfully running various innovative projects.

It is expected to satisfy the staff demand in the following ways:

- teaching senior students the "Innovative High Technology Management" course;

- advanced training of personnel for working in the existing and future innovative infrastructure organizations.

At the same time, it is worth admitting that training of professionals working in the specialized sector of the innovative economy is one of the multiple tasks of providing the innovative development economy with staff. It is evident that the competition capacity of the innovative economy is majorly determined by the readiness of the whole population of the region to work under technologic innovation conditions. Many publications remark the unique role played by human factor in the innovative processes. The subject matter is the innovative model of economic behavior (or in the wider sense of the expression, the innovative form of social behavior).

The shift of the regional economy to the innovative technology platform of development requires a change in the professional and labor behavior parameters in any sphere of work (readiness for change, rapid evolution of the professional profile, ability to improve the qualification, high technological competence and professional mobility etc.). It also creates an urge for improving the capacities of the whole population of the region (as consumers of goods and services) to live under the conditions of the complicated and high-tech product market, including high-tech products of everyday use. This capacity may be a regional component for the educational programs for both general and professional education run in the region.

Thus, besides developing the specialized segment of the education service market, which is training personnel for the innovative economy sectors, the main branches of which are described in the Program, the shift of the education branch to solving strategic tasks of supplying the innovative economy of the region with sufficient personnel requires:

1) introduction of the new education results associated with the demanded key competences of any professional into the systems of general, pre-college and higher professional education and advanced training systems;

2) introduction of the new education results borne by the technological complication of the consumers' behavior into the system of general and additional education of children.

It is rational to introduce some innovative component into the program of scientist training in the post-graduate education system of the region. Besides academic researchers, this sphere needs some "manager scientists", whose success mostly depends on their ability to attract financial and managerial resources.

Moreover, in the prospective, an innovative "specialization" of the state and municipal officials, making decisions on the innovative management approaches (such as, improvement of innovative management structure or regional target program management) for the implementation of innovative mechanisms into all spheres of the region's life, are expected to be of greatest demand.

Thus, the decisions capable of providing continuity in new educational results and maintaining the continuous education system for the population of the region, not limited to 
the transformation of a single branch of the local education system, are regarded as rational and urgent.

This new task of economic reformation requires the development of a regional education system, organizing its resources to provide the staff for directing the economy towards the way of innovative activity.

It means that every sort of development is initiated with the need for adaptation to the new conditions of life. It equally refers both to personalities and organizations.

1 http://www.educat.samregion.ru/activity/Povyshenie

2 The basic document determining the innovative development in the Russian Federation for the following years is the "Main Branches of the Russian Federation Policy for Innovative Development System for the Period before 2010".

\section{References}

1. Agarkov S.A., Kuznetsova E.S., Griaznova M.O. Innovative Management and State Innovative Policy. Akademiia estestvoznaniia, 2011.

2. Hunger J.D., Wheelen T. Essentials of Strategic Management, Unity-Dana, 2011.

3. Stepanov L.V. Competition Model under Market Conditions. Akademiia estestvoznaniia, 2009.

4. Hammer M., Chumpy J. Reengineering the Corporation. Saint Petersburg University, 1997.

5. Polovinko V.S., Timoshenko O.Iu. Target Management in Human Resource Management System. Omsk State University, 2008. 


\section{Развитие}

\section{как направленное преобразование}

Е.Я. Коган

Федеральный институт развития образования Приволжский филиал

Россия, 443056, Самара, пр. Масленникова, 37

Статья посвящена проблеме смыслового содержания понятия развития. Как исходная позиция задан аспект этого понятия как прочесс адаптации крешению новой задачи. При этом полагается, что всякая новая задача, поставленная перед индивидуумом или организацией, порождает проблему несоответствия собственных ресурсов уровню поставленной задачи. Разрешение этого противоречия и составляет процесс развития. Не изыски в прошлом, не пересмотр настоящего как времяпрепровождение и симулячия деятельности не меняют существо организации. Только поставленная иель обеспечивает вектор в деятельности и задает развитие. Вне цели нет развития. Этот тезис демонстрируется как урок одного реального проекта, который в деталях рассмотрен в статье в логике развития организации. Показан системный принции развития, необходимость адаптировать $к$ новой задаче существуюшую инфраструктуру и построение новой, сменить основы организации подготовки кадров. По существу, потребовался реинжиниринг бизнес-прочесса кадрового обеспечения быстро меняющихся технологий современного производства. В результате предполагается формирование адаптивной модели организации образовательных ресурсов, что обеспечит в рамках обозначенной парадигмы экономического развития региона режим самостоятельной адаптации к меняющимся запросам трудовых рынков.

Ключевые слова: развитие, трудовые рынки, адаптация, образовательные ресурсы, человеческий потенциал, кадры.

Научная спещиальность: 13.00.00 - педагогические науки, 19.00.00-nсихологические науки. 